Cell Research (2001); 11(2):135-141

\title{
Maternal zinc deficiency impairs brain nestin expression in prenatal and postnatal mice
}

\author{
WANG Fu Di ${ }^{1,2}$, Wei BIAN ${ }^{1}$, Ling Wei KONG ${ }^{1}$, FA Ji ZHAO ${ }^{2}$, Jun Sheng GUO ${ }^{2}$, NAi He JING ${ }^{1, *}$ \\ 1 Institute of Biochemistry and Cell Biology, Shanghai Institutes for Biological Sciences, Chinese Academy of \\ Sciences, 320 Yue Yang Road, Shanghai 200031, China \\ 2 Department of Public Health, Second Military Medical University, Shanghai 200433, China
}

\begin{abstract}
Effects of maternal dietary zinc deficiency on prenatal and postnatal brain development were investigated in ICR strain mice. From d 1 of pregnancy (E0) until postnatal d 20 (P20), maternal mice were fed experimental diets that contained $1 \mathrm{mg} \mathrm{Zn/kg/day} \mathrm{(severe} \mathrm{zinc} \mathrm{deficient,} \mathrm{SZD),} 5 \mathrm{mg} \mathrm{Zn/kg/day} \mathrm{(marginal} \mathrm{zinc}$ deficient, MZD), $30 \mathrm{mg} \mathrm{Zn/kg/day} \mathrm{(zinc} \mathrm{adequately} \mathrm{supplied,} \mathrm{ZA)} \mathrm{or} 100 \mathrm{mg} \mathrm{Zn/kg/day} \mathrm{(zinc} \mathrm{supplemented,}$ ZS and pair-fed, PF). Brains of offspring from these dietary groups were examined at various developmental stages for expression of nestin, an intermediate filament protein found in neural stem cells and young neurons. Immunocytochemistry showed nestin expression in neural tube $10.5 \mathrm{~d}$ post citrus (dpc) as well as in the cerebral cortex and neural tube from $10.5 \mathrm{dpc}$ to postnatal d 10 (P10). Nestin immunoreactivities in both brain and neural tube of those zinc-supplemented control groups (ZA, ZS, PF) were stronger than those in zinc-deficient groups (SZD and MZD). Western blot analysis confirmed that nestin levels in pooled brain extracts from each of the zinc-supplemented groups (ZA, ZS, PF) were much higher than those from the zinc-deficient groups (SZD and MZD) from 10.5 dpc to P10. Immunostaining and Western blots showed no detectable nestin in any of the experimental and control group brains after P20. These observations of an association between maternal zinc deficiency and decreased nestin protein levels in brains of offspring suggest that zinc deficiency suppresses development of neural stem cells, an effect which may lead to neuroanatomical and behavioral abnormalities in adults.
\end{abstract}

Key words: Zinc deficiency, nestin, brain development, neural stem cells.

\section{INTRODUCTION}

Zinc is essential for normal brain development, evidenced by the fact that zinc deficiency in lactating mothers is characterized by a high incidence of neuroanatomical malformations and functional abnormalities in suckling offspring[1-3]. By contrast, relatively little is known about the relationship between maternal zinc nutrition and fetal brain

Abbreviations used: dpc, days post coitus; P1, postnatal day 1. Dietary group abbreviations: SZD, severe zinc deficient diet ( $1 \mathrm{mg} \mathrm{Zn/kg/day} \mathrm{diet);} \mathrm{MZD.} \mathrm{mar-}$ ginal zinc deficient diet ( $5 \mathrm{mg} \mathrm{Zn} / \mathrm{kg} /$ day diet); ZA, zinc adequately supplied diet (30 mg Zn/kg/day diet); ZS, zinc supplemented supplied diet (100 mg Zn/kg/day diet); PF, Pair-Fed group, dietary zinc concentration is $100 \mathrm{mg} \mathrm{Zn/kg/day} \mathrm{diet,}$ but its dietary allowance was same as the ZSD group.

* Corresponding author, Tel: +86-21-64374430, Fax: +86-21-

64338357 E-mail: njing@server.shcnc.ac.cn

Received Feb-12-2001 Revised April-2-2001 Accepted April-3-2001 development[2],[4], [5]. Dvergsten et al[6-8] investigated the effects of maternal zinc deficiency on postnatal development of the rat cerebellar cortex. Granule cell neurons were sharply reduced in cell number, Purkinje cell maturation was impaired, and differentiation of basket and stellate cell dendrites was reduced. In other studies, adult rats showed significant learning and memory deficits if their mothers were mildly or severely zinc deficient during late pregnancy and lactation[9],[10]. In our previous studies, we used a different model, in which maternal zinc deficiency was initiated on the first day of pregnancy and continued throughout the period of lactation. We found impairments of learning and memory and reductions in long-term 
potentiation (LTP) in adult mice. The abnormalities were not reversed by dietary zinc supplementation after weaning[11]. Whether these results may be attributed to molecular defects in neural precursor cell proliferation and differentiation is unknown.

Nestin, a type VI intermediate filament protein of the cytoskeleton, was originally found in neuroepithelial stem cells of the rat neural tube[12], [13]. Nestin expression coincided with the proliferation of these neural stem cells[14-16], suggesting that it plays a crucial role in cytoskeletal changes that accompany neuronal differentiation and synaptogenesis. Nestin protein is now widely used as a specific marker for neural stem cells in animals and humans[17]. Here we report that nestin protein levels are decreased in embryonic and newborn mouse brains at various developmental stages where mothers are zinc deficient from the first day of pregnancy.

\section{MATERIALS AND METHODS}

\section{Mice and diets}

ICR strain mice (Shanghai Experimental Animal Center, Shanghai, China) were housed in suspended, stainless steel cages supplied with double-distilled drinking water, and were maintained in a $12 \mathrm{~h}$ light:dark cycle and temperature -controlled $\left(22-25^{\circ} \mathrm{C}\right)$ animal room. For time mating, female mice were placed in cages with males ( $\mathrm{F}: \mathrm{M}=2: 1$ ) at 16:00, and they were examined for vaginal plugs at 09:00 the following morning. The day on which a vaginal plug was detected was designated as $0.5 \mathrm{~d}$ post coitus (dpc). The day on which litters were born was designated as postnatal day 1 (P1). Zinc deficient mice have a normal gestation period of 19-21 d. Experimental diets were prepared in the same way as AIN-93G[18]. At $0.5 \mathrm{dpc}, 80$ pregnant mice were randomly assigned to one of five groups (16 mice/group): severely zinc deficient group (SZD, $1 \mathrm{mg} \mathrm{Zn/kg/day} \mathrm{diet),} \mathrm{margin-}$ ally zinc deficient group (MZD, $5 \mathrm{mg} \mathrm{Zn/kg/day} \mathrm{diet),} \mathrm{zinc} \mathrm{ad-}$ equately supplied group (ZA, $30 \mathrm{mg} \mathrm{Zn/kg/day} \mathrm{diet),} \mathrm{zinc} \mathrm{supple-}$ mented group (ZS, $100 \mathrm{mg} \mathrm{Zn} / \mathrm{kg} /$ day diet) and pair-fed group (PF, $100 \mathrm{mg} \mathrm{Zn/kg/day} \mathrm{diet).} \mathrm{From} \mathrm{the} \mathrm{first} \mathrm{day} \mathrm{of} \mathrm{pregnancy} \mathrm{to}$ the end of lactation maternal mice were fed experimental diets, and all newborn mice from each group were supplied with normal food after weaning. For the PF group, each mouse was fed the PF diet daily in amounts equal to that consumed in the previous $24 \mathrm{~h}$ by its SZD paired mate. Because severe zinc deficiency is known to affect appetite, we presumed that a higher zinc level for the pair-fed group would have more apparent effects on brain development. Based on this assumption, we chose $100 \mathrm{mg} \mathrm{Zn/kg/day} \mathrm{instead} \mathrm{of} 30 \mathrm{mg} \mathrm{Zn/kg/day} \mathrm{for} \mathrm{the} \mathrm{PF} \mathrm{group.}$ Tissue samples for biochemical extraction and immunohistochemical staining were taken from embryos (10.5 dps and 15.
$5 \mathrm{dpc}$ ) as well as from postnatal (P1, P5, P10, P20) and adult (P70) male and female brains. Tissues were fixed in $4 \%$ paraformaldehyde (PFA, Sigma-Aldrich Fine Chemicals, St. Louis, MO) in phosphate-buffered saline (PBS) at $4^{\circ} \mathrm{C}$ for $2-4 \mathrm{~h}$, dehydrated in increasing concentrations of ethanol, embedded in $52-54^{\circ} \mathrm{C}$ polyester wax and sectioned as described previously[19].

\section{Immunohistochemistry}

Polyester wax-embedded tissues were sectioned at a thickness of $8 \mathrm{~mm}$ and mounted on egg albumin-coated glass slides. Prior to immunostaining, sections were dewaxed in xylene rehydrated in gradual ethanol and in PBS at $4^{\circ} \mathrm{C}$. To block non-specific binding of antibody, sections were incubated in PBS containing $1 \%$ bovine serum albumin (BSA, Sigma) and $0.5 \%$ normal goat serum (NGS, GIBCO) for $15 \mathrm{~min}$ at room temperature. Polyclonal rabbit anti-mouse nestin IgG[16], [20] was diluted 1: 200 in blocking solution and was applied to sections overnight at $4^{\circ} \mathrm{C}$. Normal rabbit IgG was used as negative control. After rinsing slides in cold PBS three times, FITC-conjugated goat anti-rabbit IgG (TAGO, Burlingame, CA) diluted at 1:200 was applied for $30 \mathrm{~min}$ at room temperature. Finally, slides were washed in PBS, and mounted with coverslips 50\% non-fluorescent glycerol in PBS. Photomicrography was performed with an Olympus BX50 fluorescence microscope (Olympus, Tokyo, Japan). Five to ten embryos or newborn mice from each group were examined immunocytochemically, and micrography was performed in an investigator-blinded format.

\section{Western blot}

Rapidly dissected tissue samples (100 mg-1 g) from 5-10 animals were pooled and weighed. After chilling the samples to $4^{\circ} \mathrm{C}$, three volumes of extraction buffer $(150 \mathrm{M} \mathrm{NaCl}, 0.5 \mathrm{M}$ urea, $20 \mathrm{mM}$ EDTA, $10 \mathrm{~m}$ M EGTA, $0.25 \mathrm{mM}$ PMSF, $1 \mathrm{mg} / \mathrm{ml}$ aprotinin, $1 \mathrm{mM}$ dithiothreitol, and $0.5 \%$ SDS in $50 \mathrm{mM}$ Tris- $\mathrm{HCl}, \mathrm{pH}$ 8.3) were added, and homogenized mechanically. Protein concentration in homogenates was estimated by measuring absorbance at $280 \mathrm{~nm}$ using extraction buffer as a blank. Equal amounts of protein were precipitated in $70 \%$ ethanol that extracted soluble lipids, and the pellet after centrifugation was redissolved in $50 \mu \mathrm{l}$ of gel loading buffer. After boiling for $5 \mathrm{~min}$, protein samples corresponding to $20 \mu \mathrm{g}$ per lane were electrophoresed in an $8 \%$ SDS-PAGE gel. Proteins were electrophoretically transferred to nitrocellulose membranes (Amersham Pharmacia, Hong Kong, China) using a Trans-Blot cell (Bio-Rad, Hercules, CA) at $30 \mathrm{~V}$ constant voltage overnight at $4^{\circ} \mathrm{C}[21]$. Non-specific protein binding sites on the membrane were blocked by soaking the blots in 1\% BSA and 5\% NGS in PBS for $3 \mathrm{~h}$ at room temperature. After a quick rinse in PBS, blots were incubated in nestin specific antibody[16, 20] diluted 1:200 in 1\% BSA, 5\% NGS in PBS overnight at $4^{\circ} \mathrm{C}$. Membranes were washed twice for $15 \mathrm{~min}$ in PBS, $1 \%$ BSA, $0.01 \%$ Tween-20, and a secondary antibody, goat anti-rabbit IgG-AP (1:500, Zymed, San Francisco, CA) was applied for $1 \mathrm{~h}$. After a final wash in PBS, blots were immersed in chromogen solution consisting of $0.15 \mathrm{mg} / \mathrm{ml} 5$-bromo-4-chloro3-indolyl phosphate (BCIP, Sigma) and $0.3 \mathrm{mg} / \mathrm{ml}$ nitro blue tetrazolium (NBT, Sigma) in $0.1 \mathrm{M} \mathrm{NaCl}, 50 \mathrm{mM} \mathrm{MgCl}_{2}, 0.1 \mathrm{M}$ Tris-HCl, pH 9.5 in dark for 5 min at room temperature. The 
reaction was stopped by immersing the blot in $1 \mathrm{mM}$ EDTA, 20 $\mathrm{mM}$ Tris-HCl, $\mathrm{pH}$ 7.9.

\section{Densitometry}

Relative densities of immunoreactive bands on Western blots were calculated from the area of the peak corresponding to the $240 \mathrm{kDa}$ band of mouse nestin after recording the blot image with a UVP CCD video camera GRAB-IT 2.59 and analyzing the image with Gelworks 1D Advanced computer software (UVP Ltd., USA).

\section{RESULTS}

Decreased nestin immunoreactivity in the brains of embryos and postnatal mice with zinc deficiency

To compare nestin expression levels in different zinc-deficient groups, immunocytochemistry was performed on the developing brain of embryos and pups on $10.5 \mathrm{dpc}, 15.5 \mathrm{dpc}$, postnatal day 1, 5 and 10 (P1, P5 and P10). Brains from five to ten em-
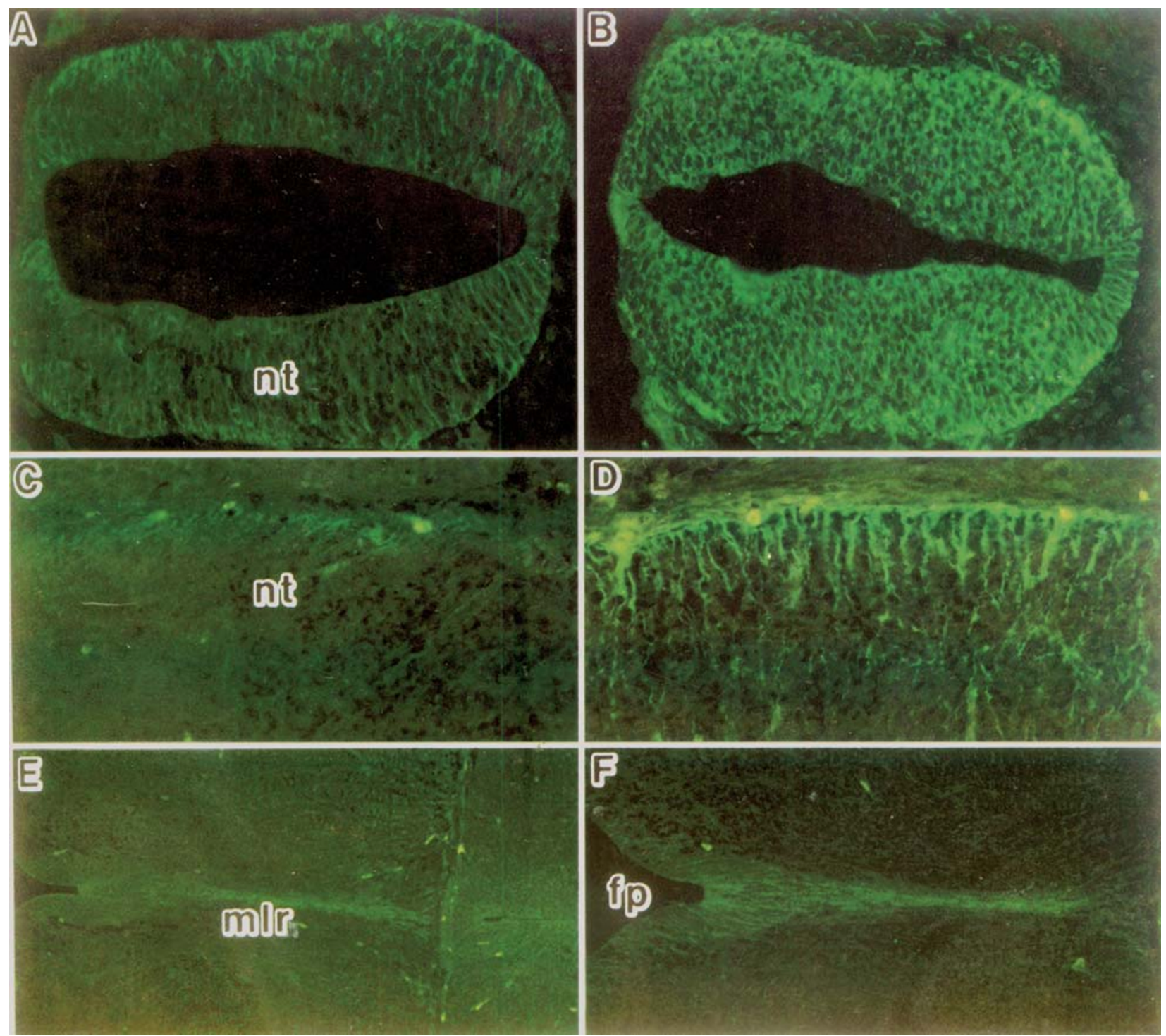

Fig 1. Immunocytochemistry of nestin protein in the neural tube of mouse embryos from mothers with different degrees of dietary zinc deficiency. A, C, and E: representatives of the severe zinc deficient (SZD) group. B, D, and F: representatives of the control zinc supplemented (ZS) group. Sections of $10.5 \mathrm{dpc}$ neural tube (A, B), $15.5 \mathrm{dpc}$ spinal cord (C, D) and brain (E, F) were probed with anti-mouse nestin IgG and FITC conjugated secondary antibody. Note that the intensity of nestin immunoreactivity in the SZD group ( $1 \mathrm{mg} \mathrm{Zn} / \mathrm{kg} /$ day diet; A, C, E) was much weaker than that in the control ZS group (100 mg Zn/kg/day diet; B, D, F). nt: neural tube; fp: floor plate of third ventricle; mlr: medial lemniscus region. A, B, E, F: scale bar $=100 \mu \mathrm{m}$. C, D: scale bar $=50 \mu \mathrm{m}$. 
bryos or newborn mice in each group were probed with anti-mouse nestin antibody. The intensity of immunostaining was at the same level within each group, and representatives from the SZD group (1 $\mathrm{mg} \mathrm{Zn/kg/day} \mathrm{diet)} \mathrm{and} \mathrm{the} \mathrm{ZS} \mathrm{group} \mathrm{(100} \mathrm{mg} \mathrm{Zn/}$ $\mathrm{kg} /$ day diet) are shown in Fig 1 and Fig 2. Nestin immunoreactivity levels paralleled zinc-supplementation levels, suggesting that more zinc in the mother's food resulted in higher expression of nestin protein in the prenatal and postnatal brain.

In early embryonic stages, nestin immunoreac- tivity was observed mainly in the neuroepithelium of the neural tube. At $10.5 \mathrm{dpc}$, nestin immunoreactivity in radial glial cells of the neural tube was stronger in ZS embryos than SZD embryos (Fig 1A and B). By $15.5 \mathrm{dpc}$, nestin immunoreactivity was prominent in the endfeet of radial glial cell as well as apical region of the neural tube of ZS embryos, but it was very weak in the neural tube of SZD embryos (Fig 1C and D). In the floor plate of the third ventricle and medial lemniscus region of the brain on $15.5 \mathrm{dpc}$, ZS group immunoreactivity of

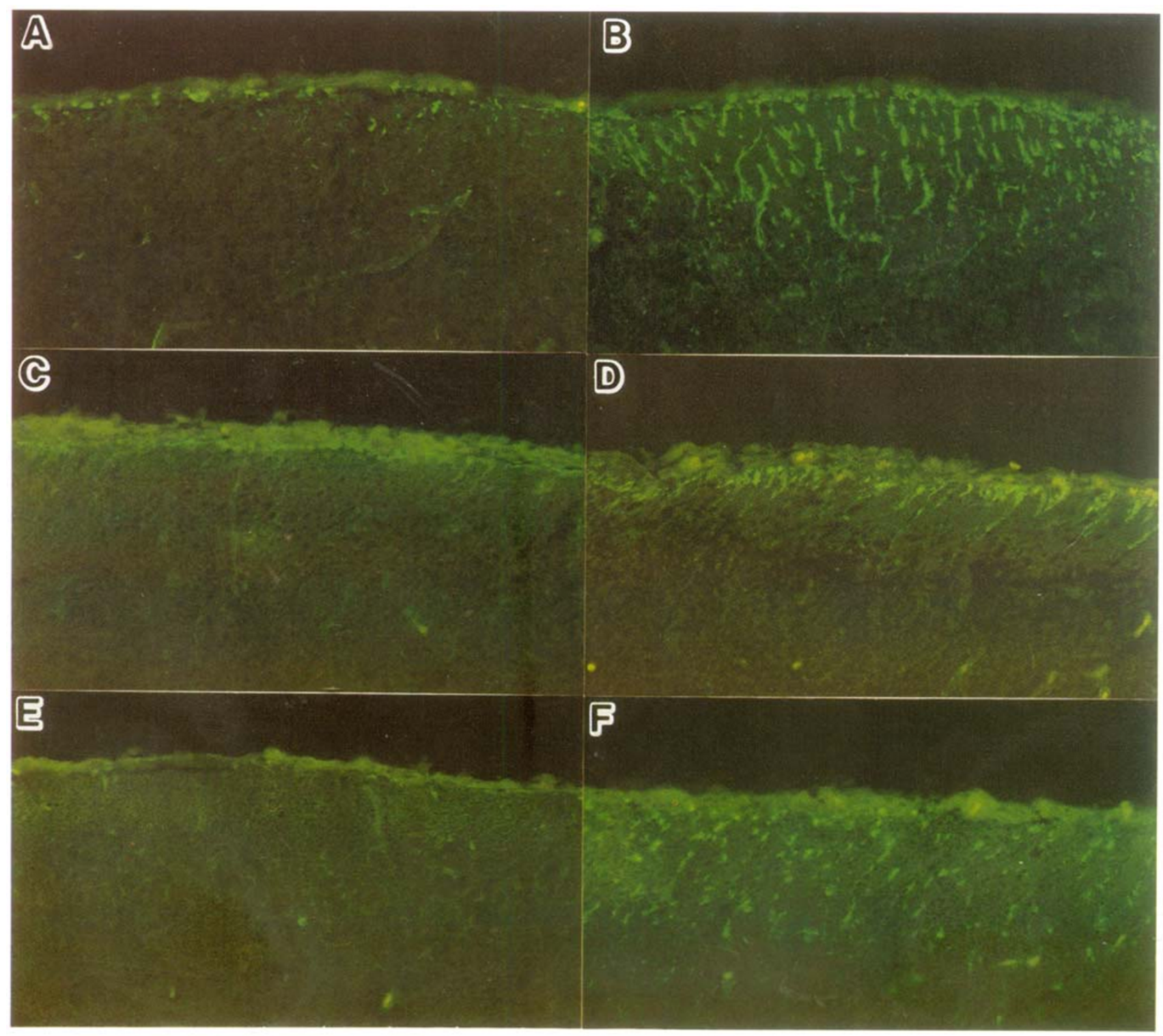

Fig 2. Immunocytochemistry of nestin protein in cerebral cortex of postnatal mice from mothers with different degrees of dietary zinc deficiency. Nestin expression in cerebral cortex of P1 (A, B), P5 (C, D) and P10 (E, F) mice was detected by immunostaining with anti-mouse nestin. Note that the immunoreactivity in the severe zinc deficiency (SZD) group (1 mg Zn/ $\mathrm{kg}$ /day diet; A, C, E) was much weaker than that in the zinc supplemented (ZS) control group (100 mg Zn/kg/day diet; B, D, F). Scale bar $=100 \mu \mathrm{m}$. 
was stronger than that of the SZD group (Fig 1E and F).

After birth, the nestin immunoreactivity localized mainly in the cerebral and cerebellar cortex. Immunostaining intensity in the cerebral cortex of the ZS group (Fig 2B, D and F) was much stronger than that in the zinc-deficient group (SZD) (Fig 2A, $\mathrm{C}$ and $\mathrm{E})$. Brain nestin immunoreactivity was absent in brains after postnatal day 20 (data not shown).

Impaired expression of nestin protein in the developing brains of zinc deficient mice

In view of the immunostaining results, we sought independent evidence to confirm impaired nestin protein expression in the zinc-deficient group. Western blots of pooled brain extracts were used to measure nestin protein levels in all five groups (Fig 3). Tissue homogenates derived from the head

A $\begin{array}{llllllllllllllllllll}1 & 2 & 3 & 4 & 5 & 6 & 7 & 8 & 9 & 10 & 11 & 12 & 13 & 14 & 15 & 16 & 17 & 18 & 19 & 20\end{array}$
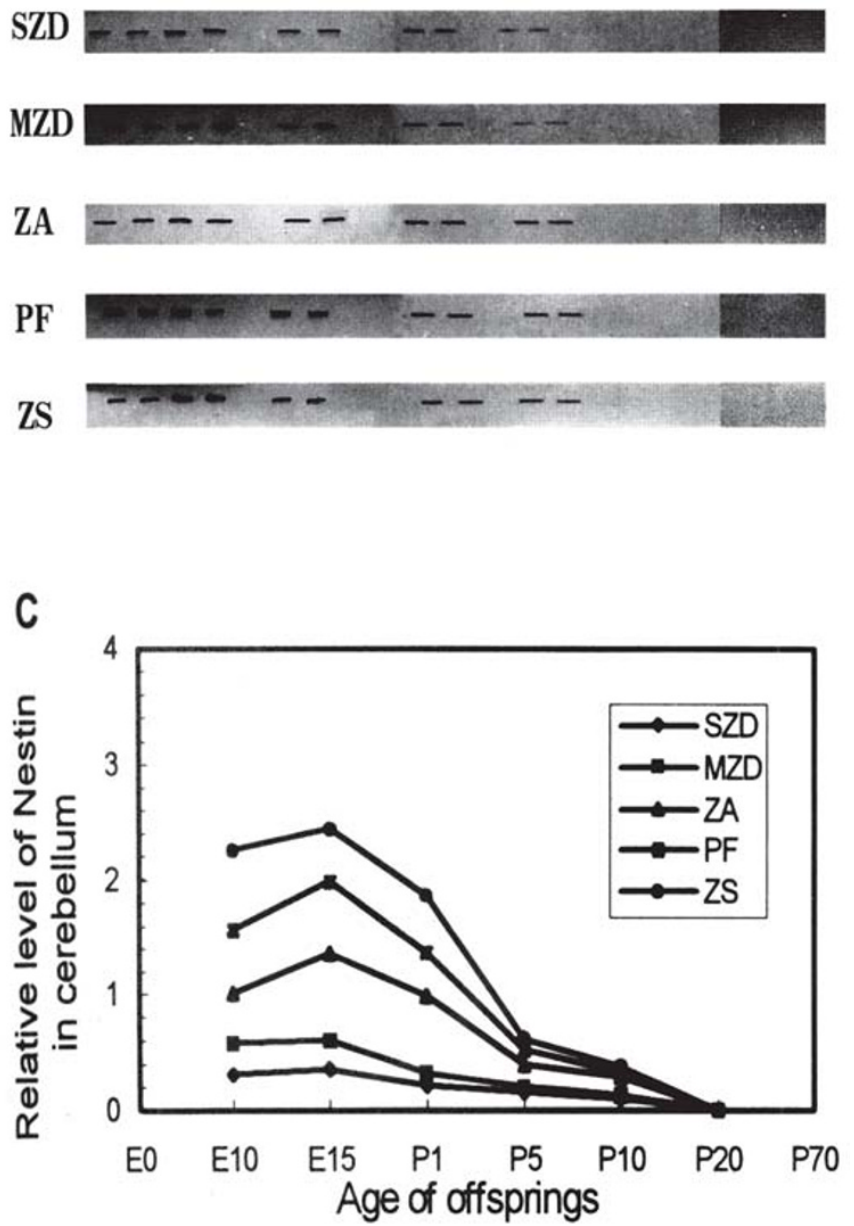

and body at $10.5 \mathrm{dpc}$, and from the cerebrum and cerebellum at $15.5 \mathrm{dpc}, \mathrm{P} 1, \mathrm{P} 5, \mathrm{P} 10, \mathrm{P} 20$, and P70 were subjected to SDS-PAGE followed by Western blot analysis using anti-nestin antibody. A single immunoreactive polypeptide band at $240 \mathrm{kDa}$ corresponding to the molecular weight of mouse nestin [12], [16],[20] was visible in brain extracts from all groups from 10.5 dpc to P10 (Fig 3A). Consistent with the immunocytochemical observations, nestin protein was not detected in brains from different groups at P20 and P70. Densitometry of the immunoreactive of bands on Western blots showed that nestin protein was expressed at its highest level on 15.5 dpc gradually decreasing until postnatal d 20 (Fig 3B and 3C). Also consistent with the immunocytochemistry, nestin protein expression in the cerebrum (Fig 3B) and cerebellum (Fig 3C) of different groups correlated well with the amount

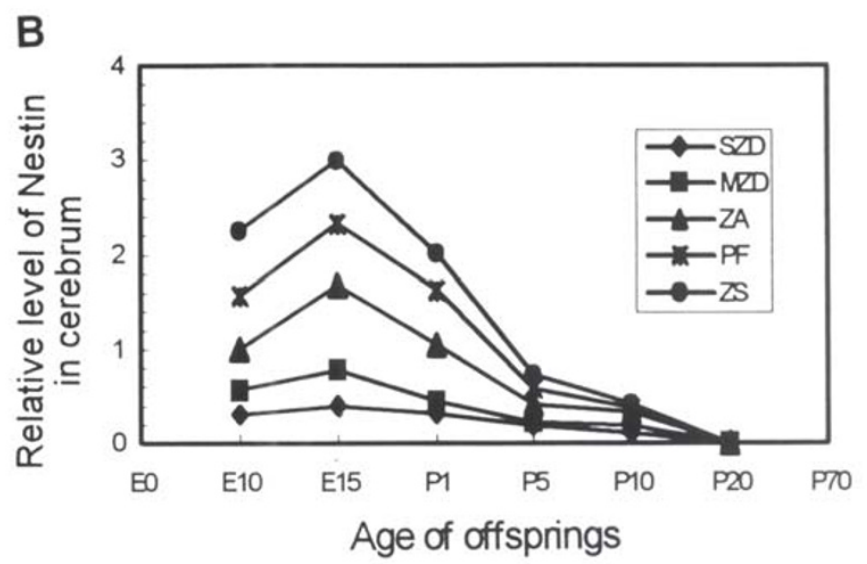

Fig 3. Western blots of nestin protein in brains of offspring from mothers with dietary zinc deficiency. Panel A: Blots of prenatal and postnatal brain extracts probed with antimouse nestin IgG. Samples from pooled extracts of 5-10 brains were analyzed: $10.5 \mathrm{dpc}$ heads (Lane 1), $10.5 \mathrm{dpc}$ bodies (Lane 2), 15.5 dpc cerebrum (Lane 3), 15.5 dpc cerebellum (Lane 4), 15.5 dpc liver (Lane 5), P1 cerebrum (Lane 6), P1 cerebellum (Lane 7), P1 liver (Lane 8), P5 cerebrum (Lane 9), P5 cerebellum (Lane 10), P5 liver (Lane 11), P10 cerebrum (Lane 12), P10 cerebellum (Lane 13), P10 liver (Lane 14), P20 cerebrum (Lane 15), P20 cerebellum (Lane 16), P20 liver (Lane 17), P70 cerebrum (Lane 18), P70 cerebellum (Lane 19) and P70 liver (Lane 20). Panel B: Graphic depiction of nestin protein levels in the cerebrum of offspring from mothers with zinc deficiency. Relative densitometry of immunoreactive bands plotted versus age: SZD and MZD groups are zinc deficient; ZA, ZS, and PF groups are controls. Panel C: Relative levels of nestin protein in cerebellum analyzed by the same method. 
of zinc in the mother's food. The relative amount of nestin protein in the developing brain was as following: SZD group (1 mg Zn/kg/day) < MZD group (5 mg Zn/kg/day) < ZA group (30 mg Zn/kg/ day) $<$ PF group (100 mg Zn/kg/day $)<$ ZS group (100 mg Zn/kg/day).

\section{DISCUSSION}

Zinc is essential for the normal embryogenesis and early postnatal development of brain. Blamberg et al[22] first described teratological effects of maternal zinc deficiency in chicks, and Hurley and Swenerton[23] reported malformations in rat pups caused by maternal zinc deficiency in early pregnancy. Maternal zinc deprivation during the last one third of pregnancy in rats and monkeys adversely affected subsequent behavior of offspring [24]. Similarly impairments in learning and memory impairment were observed in adult rats whose mothers were subjected to severe zinc deficiency during pregnancy and lactation[9],[10]. Histological abnormalities were evident in the cerebellum and hippocampus in rats with late prenatal and/or early postnatal zinc deficiency[6-8], [25], [26]. Severe zinc deficiency imposed throughout pregnancy by with diets containing less than $1 \mathrm{mg}$ $\mathrm{Zn} / \mathrm{kg} /$ day resulted in gross anatomaical abnormalities in offspring. These included agenesis and malformation of the brain, spinal cord, eye, and olfactory tract[27]. While these studies imply a crucial role for zinc in normal brain development, the molecular mechanisms are remaining poorly understood.

Nestin protein appears first in neuroepithelial cells of the neural tube after closure in mouse embryos at $9.0 \mathrm{dpc}$. Thereafter, it is expressed by neural stem cells and young neurons in the ventricular and subventricular zones of the developing brain. Nestin expression declines in the newborn brain, and it ceases in the adult brain [12],[16]. Thus, nestin is wildly used as a marker for neural stem cells during CNS development. In the present study, nestin protein levels in the developing brains of zinc deficient groups (SZD and MZD) were lower than those of zinc supplemented groups (ZA and ZS), and the levels correlated with the amount of dietary zinc consumed by the mother. The amount of nestin protein in brains of the PF group was higher than that in the ZA group, suggesting that zinc concentration is more important than quantity of food ingested for maintaining nestin protein levels.

Maternal zinc deficiency appears to disturb brain tubulin assembly in rats[28],[29], and it also alters brain myelin protein profiles in monkeys[30]. Using microtubule-associated protein 2 and neurofilament $160 \mathrm{kDa}$ as a marker for neurons and glial fibrillary acidic protein as a marker for astrocytes, we reported previously a decrease in expression of these proteins in the brains of mice with dietary zinc deficiency[31]. In the present study, possible explanations for the observed relationship between maternal zinc deficiency and reduced brain nestin levels in offspring may include the following: 1) A direct inhibitory effect on nestin gene transcription or translation; 2) Suppression of neural precursor cell DNA replication and neural cell growth. Further studies are needed to distinguish these alternatives. Nevertheless, recognition of the zinc-dependency of nestin expression in the fetal brain offers a new perspective from which to analyze the metabolic effects of trace minerals such as zinc during pregnancy.

\section{ACKNOWLEDGMENTS}

The authors thank Dr. Robert SHIURBA and Jiarui WU for their critical reading of this manuscript.

This work was supported by grants from National Basic Research Program (G 1999054000) and National Natural Science Foundation of China (No. 39770643, 39870283, 39970641), the Young Medicine Funds 1995's of the Army (No. 98Q043).

\section{REFERENCES}

[1] Sandstead HH. Zinc: essentiality for brain development and function. Nutrition Reviews 1985; 43:129-37.

[2] Wallwork JC Zinc and the central nervous system. Progress in Food and Nutrition Sciences 1987; 11:203-47.

[3] Wallwork JC, Sandstead HH. Zinc and brain function. Progress in Clinical and Biological Research 1993; 380: 65-80.

[4] Dreosti IE. Zinc and the central nervous system. In: [IE Dreosti and RM Smith, eds]. Neurobiology of the Trace Elements, New Jersey: Humana Press 1983; 1:135-62.

[5] Prohaska JR. Functions of trace elements in brain metabolism. Physiology Reviews 1987; 67:858-901.

[6] Dvergsten CL, Fosmire GJ, Ollerich DA, Sandstead HH Alterations in the postnatal development of the cer- 
ebellar cortex due to zinc deficiency. I. Impaired acquisition of granule cells. Brain Research 1983; 271:21726.

[7] Dvergsten CL, Fosmire GJ, Ollerich DA, Sandstead HH. Alterations in the postnatal development of the cerebellar cortex due to zinc deficiency. II. Impaired maturation of Purkinje cells. Brain Research 1984a; 318:1120.

[8] Dvergsten CL, Johnson LA, Sandstead HH. Alterations in the postnatal development of the cerebellar cortex due to zinc deficiency. III. Impaired dendritic differentiation of basket and stellate cells. Brain Research 1984b; 318:21-6.

[9] Halas ES, Eberharhardt MJ, Diers MA, Sandstead HH. Learning and memory impairment in adult rats due to severe zinc deficiency during lactation. Physiology and Behavior 1983; 30:371-81.

[10] Halas ES, Hunt CD, Eberhart MJ. Learning and memory disabilities in young adult rats from mildly zinc deficient dams. Physiology and Behavior 1986; 37:451-8.

[11] Wang FD, Zhao FJ, Guo JS, Jing NH, Ma XF, Mei ZT Effects of zinc deficiency during pregnancy and lactation of maternal mice on learning ability and hippocampal long-term potentiation of offsprings. Chinese Journal of Neuroscience 1998; 14:20-3.

[12] Hockfield S, McKay RDG. Identification of major cell classes in the developing mammalian nervous system. Journal of Neuroscience 1985; 5:3310-28.

[13] Lendahl U, Zimmerman LB, McKay RDG. CNS stem cells express a new class of intermediate filament protein. Cell 1990; 60:585-95.

[14] Frederiksen K, McKay RDG. Proliferation and differentiation of rat neuroepithelial precursor cell in vivo. Journal of Neuroscience 1988; 8:1144-51.

[15] Dahlstrand J, Lardelli M, Lendahl U. Nestin mRNA expression correlates with the central nervous system progenitor cell state in many, but not all, regions of developing central nervous system. Developmental Brain Research 1995; 84:109-29.M

[16] Jing NH, Kitani H, Morio I, Sakakura T, Tomooka Y, Shiurba R. Expression of intermediate filament nestin during mouse brain development. Chinese Journal of Physiological Sciences 1996; 12:1-9.

[17] McKay RDG. Stem cells in the central nervous system. Science 1997; 276:66-71.

[18] Reeves PG, Nielsen FH, Fahey Jr GC. AIN 93 purified diets for laboratory rodents: final report of the American Institute of Nutrition ad Hoc writing committee on the reformulation of the AIN 76A rodent diet. Journal of Nutrition 1993; 123:1939-51.

[19] Kusakabe M, Sakakura T, Nishizuka Y, Sano M, Matsukage A. Polyester wax embedding and sectioning technique for immunohistochemistry. Strain Technol- ogy 1984; 59:127-32.

[20] Tomooka Y, Kitani H, Jing N, Matsushima M, Sakakura T. Reconstruction of neural tube-like structures in vitro from primary neural stem cells. Proceedings of National Academy of Sciences USA 1993; 90:9683-7.

[21] Towbin H, Staehelin T, Gordon J. Electrophoretic transfer of proteins from polyacrylamide gels to nitrocellulose sheets: procedure and some applications. Proceedings of National Academy of Sciences USA 1979; 76:4350-4.

[22] Blamberg DL, Blackwood UB, Suplee WC, Combs GF. Effect of zinc deficiency on hatchability and embryonic development. Proceedings of Society Experimental and Biological Medicine 1960; 104:217-20.

[23] Hurley LS, Swenerton H. Congenital malformations resulting from zinc deficiency in rats. Proceedings of Society Experimental and Biological Medicine 1996; 123:692-6.

[24] Sandstead HH, Wallwork JC, Halas ES, Tucker DM, Dvergsten CL, Strobel DA. Zinc and central nervous function. In: B Sakar, edit. Biological Aspects of Metals and Metal Related Diseases New York NY: Raven Press 1983:225-41.

[25] Dreosti IE, Manuel SJ, Buckley RA, Fraser FJ, Record IR. The effect of late prenatal and /or early postnatal zinc deficiency on the development and some biochemical aspects of the cerebellum and hippocampus in rats. Life Science 1981; 28:2133-41.

[26] Halas ES, Kawamoto TC. Correlated behavioral and hippocampal effects due to prenatal zinc deprivation. In: CJ Frederickson, GA Howell and EJ Kasarakis, eds. The Neurobiology of Zinc B: deficiency, toxicity and pathology New York NY: Alan R Liss 1984:91-107.

[27] Rogers JM, Keen CL, Hurley LS. Zinc deficiency in pregnant Long Evans hooded rats: teratogenicity and tissue trace elements. Teratology 1985; 31:89-100.

[28] Oteiza PI, Hurley LS, Lonnerdal B, Keen CL. Marginal zinc deficiency affects maternal brain microtubule assembly in rats. Journal of Nutrition 1988; 118:735-8.

[29] Oteiza PI, Hurley LS, Lonnerdal B, Keen CL. Effects of marginal zinc deficiency on microtubule polymerization in the developing rat brain. Biological Trace Element Research 1990; 24:13-23.

[30] Liu H, Oteiza PI, Gershwin ME, Golub MS, Keen CL. Effects of maternal marginal zinc deficiency on myelin protein profiles in the suckling rat and infant rhesus monkey. Biological Trace Element Research 1992; 34: 55-66.

[31] Wang FD, Zhao FJ, Jing NH. Effect of dietary zinc on microtubule-associated protein 2 expression in the brain of mice. Acta Physiologica Sinica 1999; 51:495500 . 